University for Business and Technology in Kosovo

UBT Knowledge Center

UBT International Conference

2018 UBT International Conference

Oct 27th, 1:30 PM - 3:00 PM

\title{
Underground house as a new concept of housing
}

\author{
Zana Prelvukaj \\ University for Business and Technology, zana.prelvukaj@ubt-uni.net \\ Lulzim Beqiri \\ University for Business and Technology, Ibeqiri@ubt-uni.net \\ Rineta Jashari \\ University for Business and Technology, rineta.jashari@ubt-uni.net \\ Faton Spahiu \\ University for Business and Technology, faton.spahiu@ubt-uni.net
}

Follow this and additional works at: https://knowledgecenter.ubt-uni.net/conference

Part of the Architecture Commons

\section{Recommended Citation}

Prelvukaj, Zana; Beqiri, Lulzim; Jashari, Rineta; and Spahiu, Faton, "Underground house as a new concept of housing" (2018). UBT International Conference. 29.

https://knowledgecenter.ubt-uni.net/conference/2018/all-events/29

This Event is brought to you for free and open access by the Publication and Journals at UBT Knowledge Center. It has been accepted for inclusion in UBT International Conference by an authorized administrator of UBT Knowledge Center. For more information, please contact knowledge.center@ubt-uni.net. 


\title{
Underground house as a new concept of housing
}

\author{
Zana Prelvukaj ${ }^{1}$, Lulzim Beqiri ${ }^{1}$, Rineta Jashari $^{2}$, Faton Spahiu ${ }^{2}$ \\ UBT - Higher Education Institution, Lagjja Kalabria, 10000 p.n., Prishtine, \\ Kosovo \\ zana.prelvukaj@ubt-uni.net ${ }^{1}$, lbeqiri@ubt-uni.net ${ }^{1}$,rineta.jashari@ubt-uni.net ${ }^{2}$ \\ faton.spahiu@ubt-uni.net ${ }^{2}$
}

\begin{abstract}
Since the beginning of human existence, housing is considered one of the basic elements for survival and protection from difficult natural conditions.

The purpose of this research is to treat underground homes, as a new form of residence. In addition, the study will seek to discover the underground houses that were developed in Switzerland, China and Greece as constructions and that have gained good results in the field of housing, integration of outdoor construction, design and saving energy. The research is intended to serve as a basic, basis for informing the typologies, advantages, and disadvantages of the underground houses.

Moreover, the topic addresses the advantages and opportunities of underground houses that can be developed in our country, which of the typologies is preferred based on research and conditions such as the extent of the land, climate and culture that our country possesses. The research reaches to the result of the definition of typology, its function, and the project proposal that can be considered adequate under the country's conditions.
\end{abstract}

Keywords: Underground house, Kosovo, housing, typologies, efficiency

\section{Introduction}

The purpose of this research is to treat underground homes, as a new form of residence. Since the beginning of human existence, housing is considered one of the basic elements for survival and protection from difficult natural conditions. The house is the central focus of our living. Every form of lifestyle depends on nature's ability to produce clean air, clean water, fertile soil, waste recycling, etc. Every man's duty is to follow the changes and not to be an indicator of the deterioration of the destruction of nature.

A home is not home if:

- Does not provide housing for residents

- It does not save the environment where it is part

\section{Underground house in Vals, Switzerland}

In a picturesque location like Vals, in Switzerland, it is difficult to imagine any new construction that would hurt the beautiful landscape, of SeArch and Christian Müller.Built in the Swiss Vals village, the house is almost invisible, located on a mountain such as the terrain invisible.In the introductory part there is a central courtyard which is surrounded by a large facade formed by large window openings that offer bright reflections of the Alpine view on the opposite side of the narrow valley. (Pham, 2014) 

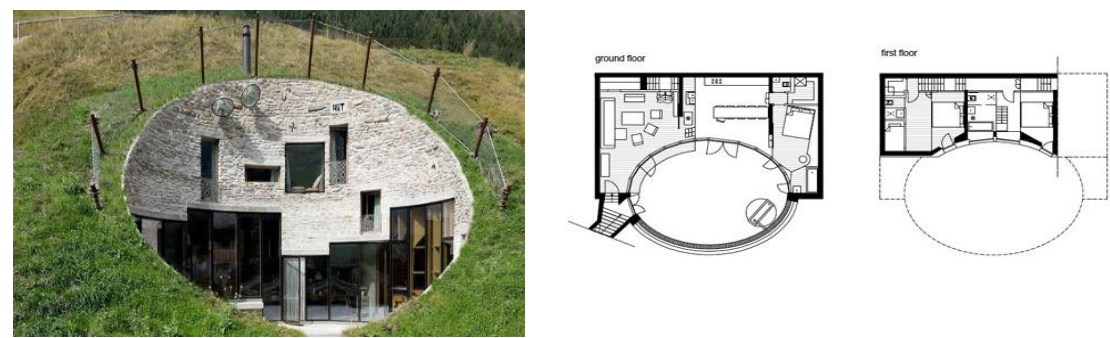

Fig 2 -Underground House in Vals, Switzerland (Pham, 2014)

Fig 3 -Underground House in Vals, Switzerland (https://inhabitat.com/aluxury-swiss-villa-nestled-beneath-the-earth/ )

\section{Aloni House Greece}

This stunning subtropical house from Deca Architecture uses a natural range of materials to keep a low profile by complementing the quiet Mediterranean landscape surrounding it.The house benefits from simple materials that maximize energy efficiency, allowing the house to melt with the rugged terrain of Greece's Antiparos island.The Alon's House Plan consists of five inner areas enclosed by four courtyards that are carved into the landscape. The interior space features large windows that allow sunlight to penetrate home while shelter and ground support protect the home from bad weather and excessive solar heat gain (Chino, 2010).

The ecological house was designed by Longhi Architects between 2006-2008

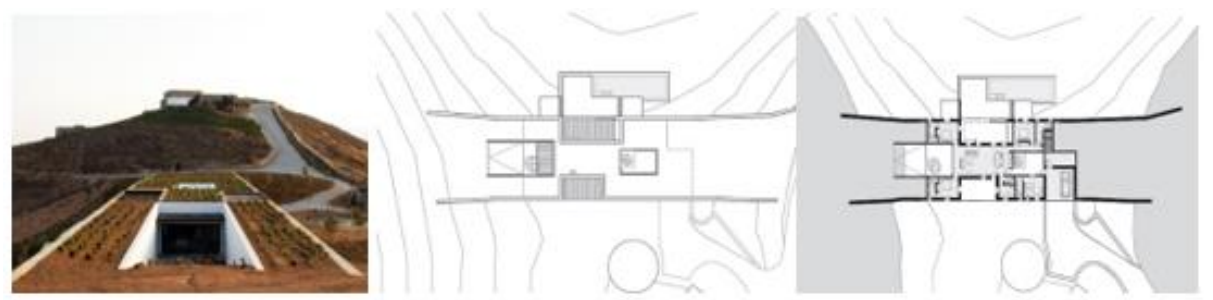

Fig4,5,6- Aloni House Greece(decaARCHITECTURE, 2010)

\section{China, underground habitats}

In the northwest of China, the variety of these structures have evolved, ranging from cave dwelling units to the most advanced underground types. In the case of traditional underground homes in China (called 'yao dong'), the rooms were dug into loose, dry ground, mainly to fight hot summers and cold winters (Anselm, 2012). Chinese culture that is in harmony with nature and its preservation.People and their culture survived here for hundreds of years without leaving any significant mark on the environment 


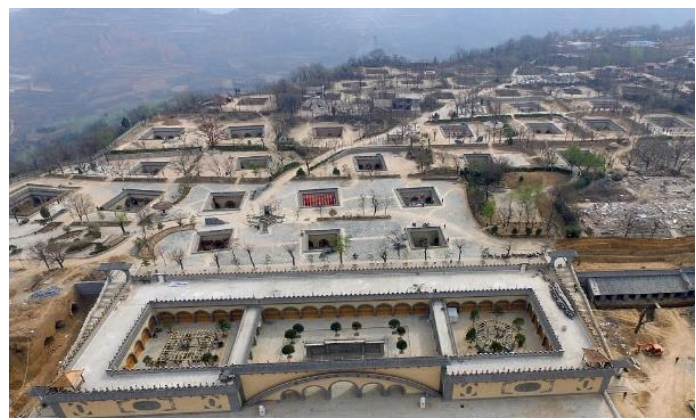

Fig 7- China, underground habitats (Anselm, 2012)

\section{Case study (Tipologys of underground houses)}

Depending on site construction and site analysis, underground homes are divided into the following categories:

- Ground floor

- Underground house with atrium

- Underground house with a free façade

- House with two facades inexpensive

- Combined House 

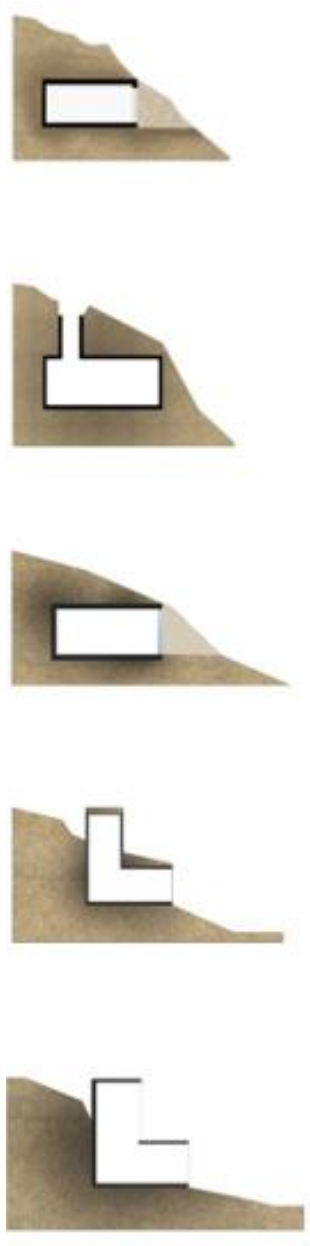

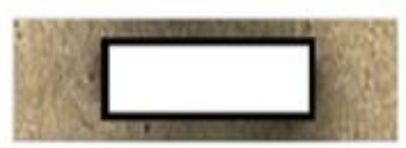

Fig 8 - Ground floor
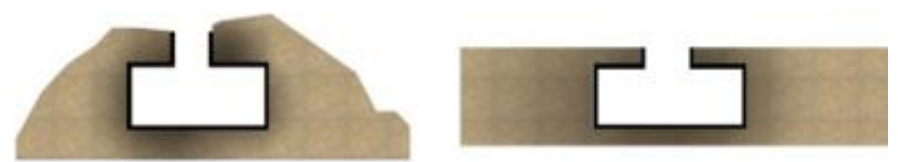

Fig 9 - Underground house with atrium

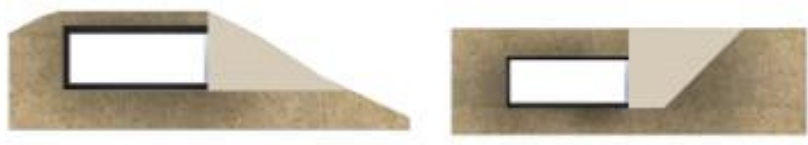

Fig 10 - Underground house with a free facade
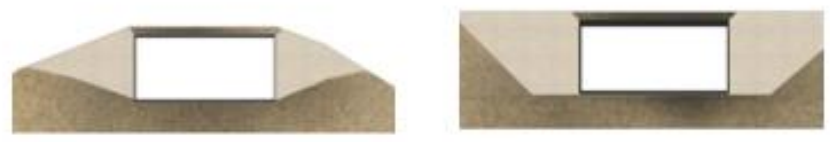

Fig 11 - House with two facades inexpensive
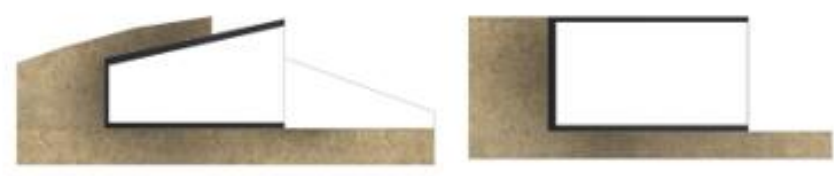

\section{Advantages of underground houses}

- The underground homes offer a safe haven from extreme weather like tornadoes, hurricanes, strong winds and volcano storms

- Underground homes are well mixed in the environment

- The earth being a natural insulator, keeps such warm homes in the winter and cold in the summer. This reduces home energy requirements, especially in windy areas

- Because of the constant temperature of underground homes, energy costs have been significantly reduced

- With proper planning and construction, these homes can have good light conditions

- These homes require little or no external maintenance, such as re-painting, thus reducing maintenance costs 
- Ground houses can be built on steep terrain surfaces

- These homes offer fewer opportunities for insects and other pests, due to the smaller number of openings

- $\quad$ These homes are almost safe from robbers and thieves when compared to traditional homes, as only one side of the home needs to be protected

\section{Disadvantages of the underground house}

- There may be a psychological adjustment needed for a person who moves from a traditional house on the ground to an underground home.

- These homes are unusual and require careful planning.

- One of the main problems with underground homes is that they can not be built in a flood-prone area

- The process of applying for construction permits and mortgages can also be challenging for these homes

- Construction of such houses requires complex procedures of ventilation, lighting, and construction

\section{Construction law in Kosovo}

The aspect of residential forms in Kosovo is quite well explained by the construction law (Spatial, 2018).Construction Law 04 / L-110, dated 31.05.2012, respectively Article 15 defines the following categories of construction:

1.1. Category I - low risk construction;

1.2. Category II - Construction of Medium Risk

1.3. Category III - Construction of high risk and construction of national interest.

Kosovo in the legislative aspect does not contain the law on the construction of underground houses (Hapësinor, 2018).

\section{Methods used for research}

A new type of residential buildings that have not yet been applied in our country and which can conclude that we do not have enough information about the conditions that the underground house can provide. The resident questionnaire asked the residents that "Would they have accepted living in a subterranean home?". Based on the obtained results, about 35\% responded by accepting to live in a subterranean home, commenting that it would be a new experience of residential function, many of them point out that these homes offer comfort in terms of the efficiency that the summer house keeps freshness and winter heat because the soil is a pretty good isolator, some of the locals support nature conservation, protection from air pollution, protection from pollution of rivers and lakes and according to them the underground house would help preserve the natural conditions. A small number of around $14 \%$ claim that they would not accept living in a subterranean home, the main reasons being the fear of lack of air and lighting and the basic conditions for living in residential areas. However, given that Kosovo has not dealt with a construction of the underground house, residents are not sufficiently informed about this construction category, about $55 \%$ of the residents have not admitted or opposed housing in the underground home. Based on this research will beat let's find that residents would be able to decide on whether we would build a subterranean house that would serve as evidence that would help the knowledge and advantages that underground homes can provide. 


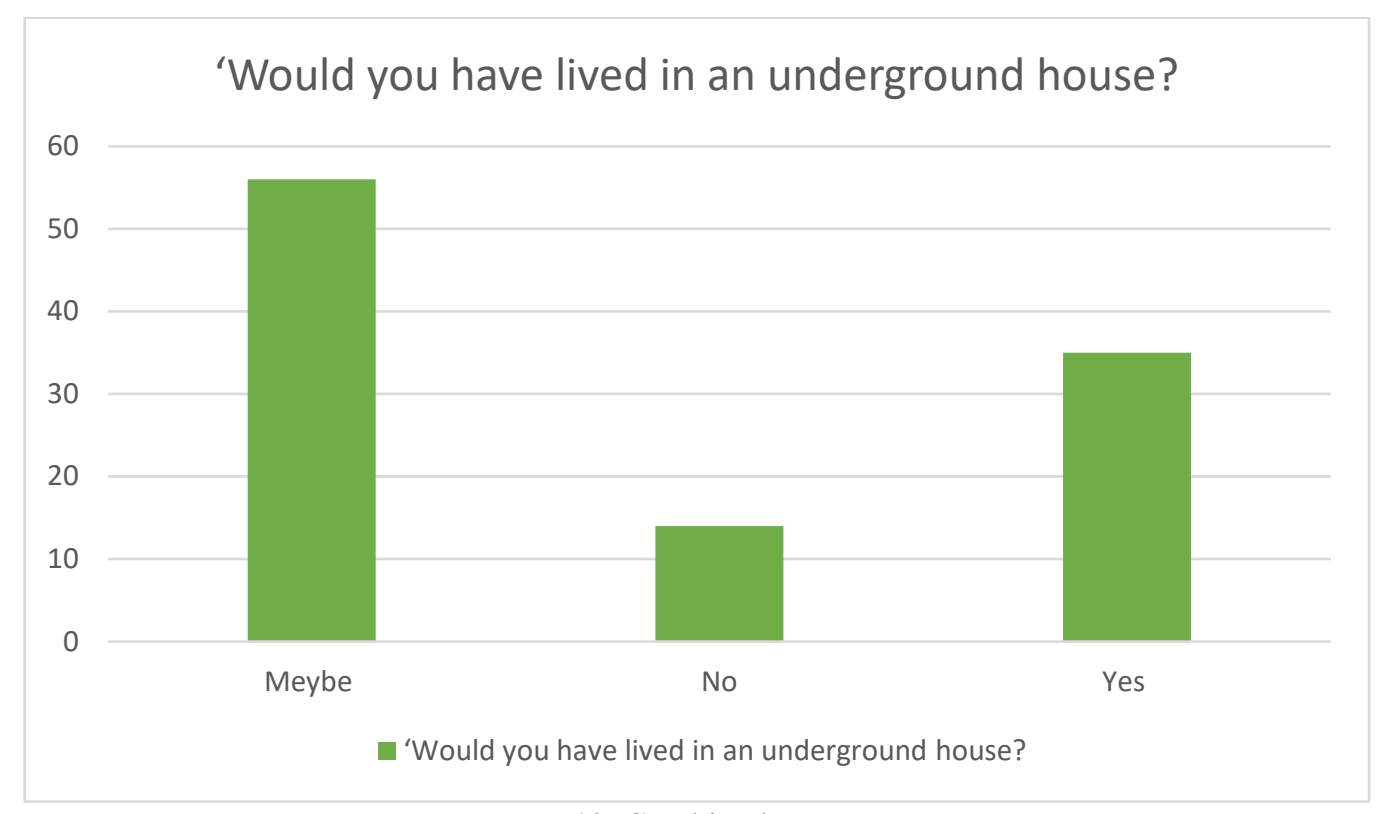

Fig 13- Combined House

\section{Conclusion}

Research has helped to determine the free form of a subterranean home that adapts to land in accordance with the principles of stamina by adapting the construction to the environment. The design of the underground home allows us to understand how we can outsource our cities to "ecological cities "with the resources offered by architectural and engineering studies.

The underground facility offers comfort in the residential area, and is considered as an efficient house that saves energy well, helps maintain environmental degradation and provides basic living conditions.

\section{Results}

The territorial expansion of Kosovo is characterized by steep and sloping terrain, which provides good conditions for the construction of these. Adequate typology according to the layout of the terrain in our country is the underground house with a free facade.

The project proposal is a demonstration of how we can make a solution to the development of tourist areas by protecting nature from the rough constructions that interfere with the degradation of the terrain and the loss of green spaces also helps to reach an energy solution with our environment living by taking part in a culture where climate change cannot transform our cities. A sustainable architecture could be a response to the problems of our city exposed by a social crisis 


\section{References}

1. Anselm, A. J., 2012. Earth Shelters; A Review of Energy Conservation. Nigeri: INTECH.

2. Dang, J. L. \&. A., 2012. Underground Dwellings in China. [Online] Available at: https://undergrounddwellings.wordpress.com/project-proposal/\#_ftnref2 [Accessed 12 Agust 2018].

3. Van der Ryn, (1996). Ecological design .Working Paper. Island ed. Washington: s.n

4. Rudolfsky, B., 1964. Architecture without architects. 1nd ed. New York: Dubleday \& Company Garden City.

5. Pham, D., 2010. Inhabitat. [Online] Available at: https://inhabitat.com/gary-nevilles-zero-carbon-underground-home/ [Accessed 5 July 2018].

6. Baile, V. i. P. M. R. T. I., 2009. EARTH SHELTERED HOUSING. Canada : New society

7. Dang, J. L. \&. A., 2012. Underground Dwellings in China.

8. Gjikolli, T., 2017. Ndertimi. 